Maternal Blood Group A and Pre-eclampsia

SIR,-We have been unable to substantiate Mr. D. P. L. May's findings (22 December, p. 738). An analysis of all primigravidae delivered of single pregnancies at St. Thomas's Hospital in 1969-70 (2,972 cases) has been carried out. In this study the diagnosis of pre-eclampsia was based on the findings at the last antenatal clinic. Mild pre-eclampsia was diagnosed when the diastolic blood pressure was $90 \mathrm{~mm} \mathrm{Hg}$ or more, with either proteinuria or oedema, and severe pre-eclampsia when the diastolic pressure was $100 \mathrm{~mm} \mathrm{Hg}$ or more, with proteinuria.

In our series 1,356 women $(45.6 \%)$ were of blood group $\mathrm{O}$ and $1,176(39 \cdot 6 \%)$ of group A. Dr. May found a very great increase in pre-eclampsia during the second half of pregnancy in women of group A compared with those of group $O$. In our cases there was very little difference between these two groups at term. The incidence of mild pre-eclampsia was $5 \cdot 10 \%$ (60 cases) in women of group A and $5.53 \%$ (75 cases) in those of group $\mathrm{O}$. The corresponding figures for severe pre-eclampsia were $0.60 \%$ (7 cases) and $1 \cdot 18 \%$ (16 cases) respectively. These differences are not significant statistically.-We are, etc.,

JOANNA SOUTH JANET NALDRETT

Department of Gynaecology, St. Thomas's Hospital Medical School, London S.E.1

\section{Training for General Practice}

SIR,-I very much appreciated the letter from Dr. J. D. Sinson (23 February, p. 327). Qualifying from a British university does not ensure education in the specialty of general practice. Let us face the fact that at present the only hope of excellence in general practice is in the organization of postgraduate training in general practice. More and more doctors should receive inducement to study general practice. This is the only way in which new recruits to general practice can fight "the lack of morale bred by professional isolation or the temptation to freewheel and to channel the most difficult and intellectually-challenging cases to the hospitals" (Dr. F. M. Hull, Personal View, 23 February, p. 325). In fact this is what the creation of more chairs of general practice in Great Britain hopes to achieve. It is high time that the present occupants of general practice had a change of mind and attitude, and when selecting new recruits into general practice they should insist on their having completed a traineeship in general practice more than on anything else. -1 am, etc.,

Ruchill Hospital,

Glasgow

\section{Work Load in General Practice}

SIR,-With regard to the second article by Dr. G. N. Marsh and Mr. R. A. McNay (23 February, p. 319) we consider that it is important to note that their reference to our paper ${ }^{1}$ is inaccurate. They state that "like Whitfield we found that female patients who had recently joined the list did cause more work, though [Bain and Haines] have disagreed." If one reads our criticism of Whitfield's article ${ }^{2}$ it is evident that we were criticizing the method by which he had reached his conclusions, and as a result of the defects in methodology we were of the opinion that Whitfield's results could not be considered accurate or meaningful.

In addition, we would take issue with the statement by $\mathrm{Dr}$. Marsh and Mr. McNay in their first article in the same issue (p. 315) that "the average list size of 2,400 patients will rapidly become too small to occupy the time of established general practitioners. . . . For the majority an increase in list size will be mandatory to satiate their clinical interests." This statement cannot be acoepted on the basis of one general practitioner's experience. It may be that Dr. Marsh cannot satisfy his clinical interests by looking after 3,000 patients, but he cannot assume that his methods of working are representative of all general practitioners in this country.-We are, etc.,

\section{J. G. BAIN}

A. J. HAINES

Craigshill Health Centre,
Livingston, West Lothian

1 Bain, D. J. G., and Haines, A. J., fournal of the Royal College of General Practitioners, 1973, 23, 73 Whitfield, M. J., Fournal of the Royal College of
General Practitioners, 1972, 22, 675.

\section{Perinatal Metabolism of Diazepam}

SIR,-We were interested to read the article by Dr. Jean E. Cree and others (3 November, p. 251) in which it was shown that diazepam and its main metabolite $\mathrm{N}$-demethyldiazepam were detectable in significant concentrations in the plasma of some infants for up to eight days postnatally if diazepam was given to the mothers less than 15 hours before delivery. We have found that diazepam and $N$-demethyldiazepam cross the placenta both in early ${ }^{1}$ and in late pregnancy. ${ }^{2}$ During subchronic use in early pregnancy diazepam accumulates in fetal tissues.' The newborn infant can also receive diazepam in the mother's milk if the mother is given diazepam post partum. ${ }^{4}$

To clarify the perinatal metabolism of diazepam we have examined the concentrations of diazepam and its metabolites in five newborn babies whose mothers received $10-15 \mathrm{mg}$ diazepam daily for 6-21 days before labour for the management of mild pre-eclampsia and sleep disturbances. The final dose was given 12-15 hours before delivery. Other treatment consisted of diuretics and antihypertensives. The concentrations of diazepam and its metabolites were determined by gas chromatography. ${ }^{2}$ The percentage recoveries of diazepam, $N$-demethyldiazepam, and free oxazepam zepam, $N$-demethyldiazepam, and free oxazepam were 95,85 , and 92 in both maternal and fetal
plasma. From the urine the percentage recoveries plasma. From the urine the percent
were 97,87 , and 96 , respectively.

\begin{tabular}{|c|c|c|c|c|c|c|c|}
\hline Case no. & $\begin{array}{c}\text { Days post } \\
\text { partum }\end{array}$ & $\begin{array}{l}\text { Total daily } \\
\text { urine (ml) }\end{array}$ & $\begin{array}{l}\text { Total oxaze- } \\
\text { pam }(\mathrm{ng} / \mathrm{ml})\end{array}$ & $\begin{array}{c}\text { Glucuro- } \\
\text { nized oxaze- } \\
\text { pam (ng/ml) }\end{array}$ & $\begin{array}{l}\text { Free oxaze- } \\
\text { pam (ng/ml) }\end{array}$ & $\underset{(\mathbf{n g} / \mathrm{ml})}{\text { Diazepam }}$ & $\begin{array}{c}\text { N-Demethyl- } \\
\text { diazepam } \\
(\mathbf{n g} / \mathrm{ml})\end{array}$ \\
\hline 1 & $\begin{array}{l}2 \\
3 \\
7\end{array}$ & $\begin{array}{r}57 \\
68 \\
250\end{array}$ & $\begin{array}{l}156 \\
162 \\
139\end{array}$ & $\begin{array}{l}156 \\
162 \\
122\end{array}$ & $\overline{17}$ & $\begin{array}{r}10 \\
\mathbf{6} \\
\mathbf{3}\end{array}$ & $\begin{array}{r}30 \\
25 \\
5\end{array}$ \\
\hline 2 & $\begin{array}{l}4 \\
5 \\
6\end{array}$ & $\begin{array}{r}61 \\
200 \\
140\end{array}$ & $\begin{array}{r}48 \\
88 \\
216\end{array}$ & $\begin{array}{r}40 \\
80 \\
206\end{array}$ & $\begin{array}{r}8 \\
8 \\
10\end{array}$ & $\frac{-11}{12}$ & $\begin{array}{l}28 \\
23 \\
15\end{array}$ \\
\hline 3 & $\begin{array}{l}1 \\
4 \\
6\end{array}$ & $\begin{array}{r}64 \\
153 \\
216\end{array}$ & $\begin{array}{l}56 \\
47 \\
45\end{array}$ & $\begin{array}{r}56 \\
47 \\
45\end{array}$ & 二 & $\begin{array}{l}16 \\
15 \\
21\end{array}$ & $\begin{array}{r}114 \\
26 \\
22\end{array}$ \\
\hline \multirow[t]{2}{*}{4} & $\begin{array}{l}0 \\
2\end{array}$ & $\begin{array}{l}105 \\
125\end{array}$ & $\begin{array}{l}46 \\
34\end{array}$ & $\begin{array}{l}46 \\
34\end{array}$ & 二 & $\frac{1}{10}$ & $=$ \\
\hline & $\begin{array}{l}4 \\
2\end{array}$ & $\begin{array}{l}175 \\
150\end{array}$ & $\begin{array}{l}40 \\
69\end{array}$ & $\begin{array}{l}40 \\
69\end{array}$ & - & & - \\
\hline & 4 & $\begin{array}{r}150 \\
98\end{array}$ & $\begin{array}{l}69 \\
69\end{array}$ & $\begin{array}{l}69 \\
69\end{array}$ & 二 & $\begin{array}{l}14 \\
15\end{array}$ & $\begin{array}{l}37 \\
26\end{array}$ \\
\hline \multirow{2}{*}{5} & $\begin{array}{l}6 \\
9\end{array}$ & $\begin{array}{l}132 \\
110\end{array}$ & $\begin{array}{r}52 \\
134\end{array}$ & $\begin{array}{r}52 \\
134\end{array}$ & 二 & $\begin{array}{l}17 \\
16\end{array}$ & 13 \\
\hline & 11 & & 37 & 37 & - & 25 & - \\
\hline
\end{tabular}
methyldiazepam in the babies' plasma are shown in the accompanying figure. The results are in good agreement with the results of Dr. Cree and her colleagues. The newborn infant seems to be capable of metabolizing diazepam, but its elimfound in concentrations of $13-220 \mathrm{ng} / \mathrm{ml}$. One infant (case 4), however, had the astonishingly high plasma free oxazepam concentration of $1,231 \mathrm{ng} / \mathrm{ml}$ immediately after delivery and this level persisted for three days post partum. In adults free oxazepam is found only in negligible concentrations. Our results give support to current
views on the low glucuronizing capacity of the newborn with considerable individual variation.

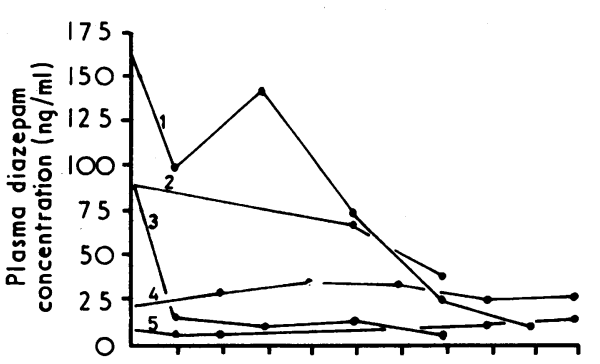

The concentrations of diazepam, $N$-demethyldiazepam, and oxazepam in the urine of the five infants are shown in the table. The main excreted component was glucuronized oxazepam, which constituted about $70 \%$ of all diazepam products in the urine. Glucuronized forms of diazepam and $N$-demethyldiazepam were not found. The infant who had the highest plasma concentration of free oxazepam (case 4) had the lowest total excretion of oxazepam (case 4) had the low

Our results indicate that there are wide individual variations in the metabolism and elimination of diazepam in the newborn. The concentrations of diazepam and its metabolites may be high enough to be pharmacologically active for up to 10 days. This can explain the respiratory difficulties, lethargy, and disturbances in thermoregulation to which Dr. Cree and her colleagues refer. Also the glucuronization of oxazepam may competitively inhibit the conjugation of bilirubin, leading to hyper-
The concentrations of diazepam and $\mathrm{N}$-deination takes at least 10 days. Free oxazepam was



